\title{
異なった種類の飼料給与時における 反㫚胃内繊毛虫類の消長
}

福島県農業共済組合連合会

吉 由 増 -

要

約

ホルスタイン種成雌牛 2 頭および黒毛和種成雌牛 2 頭を供試し、給与飼料は、粗飼料として稲わら、 青草(オーチャードグラス）、乾草（オーチャードグラス）抽びサイレージ（トウモロコシ茎葉）を、 濃厚飼料は大麦挽砕を使用した。乙れらの飼料を粗飼料単味または濃厚飼料を加えて給与するてとによ

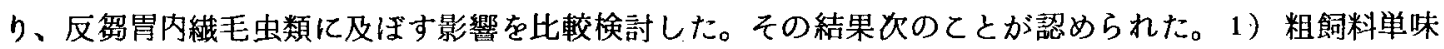

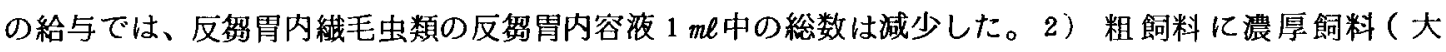

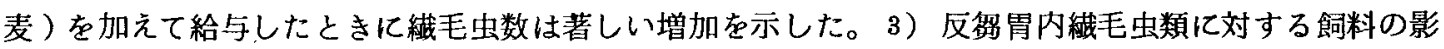
響は實毛虫類に顕著にあらわれ、特にEntodinium属は飼料組成に敏感に反応して増減した。すなわち、 織毛虫数の大多数を占めるEntodinium属は、大麦給与時に増加し、また、その中では、Entodinium simplex の数が最も顕著に增加した。4）給与飼料をもとの飼料に房すことにより、もとの繊毛中集 団構成に近くなったてとから、給与する飼料の種類が反忽胃内瀻毛虫数の重要な変動要因であると考え られだ。

反留胃内織毛虫類の種類と数を支配する要因は、種々考えられている ${ }^{1-6)}$ 。WARNER ${ }^{7)}$ にると、貧毛 虫類は豊富に濃厚飼料を給与した動物の反媰胃内に、また、全毛虫類は乾草か可溶性糖類に富んだ䒱葉 飼料を与えた動物の反第胃内に数多く生息するとしている。NAKAMURA and KANEGASAKI ${ }^{8)}$ は、メン羊 による実験を行って、飼料の組成が反架胃内繊毛虫類の構成に大きく影響するてとを認めた。その他、

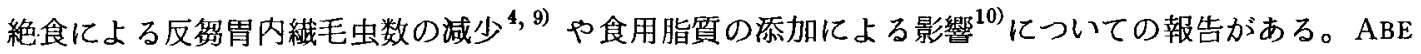
et $a l^{11}$ はフィステル装着牛を用いた実験で、濃厚飼料を給与しない場合には、筫毛虫類が著しく減少 し、濃厚飼料の給与量が多いほど筫毛虫類は増加し、さらに、繊毛虫類の維持に関して稲わらは必須で なかったと報告した。日野・亀高 ${ }^{12)}$ 山羊による実験で、オーチャード乾草と配合飼料の比率を1：2で 給与した場合に瀻毛虫数が最も多く、配合飼料無給与では繊毛虫数が減少したと述べた。しかし、配合 飼料を最も多く含む飼料を給与した場合は、最も繊毛虫数が少なかったとし、ての理由として、ての場 合急激な反䝆霄内発醉のため、繊毛虫類は不安定になるためであると説明している。

これらの報告を検討すると、給与する飼料の種類が反䖲胃内瀻毛虫類の種類と数を支配する最大の要 因であると考えられるが、しかしこれまでの多くの試験は、メン羊または山羊によるものが大部分を占 め、牛を用いた試験は極めて少いようである。そてで本試験は、成牛を用いて、給与する飼料の種類に より、反䀜胃内緎毛虫類の種類と数がどのような影響を受けるかを検討した。

\section{材料および方法}

1. 試験 1： 乾乳後同一環境下で同一埕料給与し、1 か周間飼育した 10 才および 8 才のホルス タイン種雌牛 2 頭を用いた。試験期間は、第 I 期、第 II 期および第盀期に区分し、各期を 15 日間とし 
た。給与飼料は、第 I 期が大麦挽砕 $6 \mathrm{Kg}$ 十稲わら $3 \mathrm{Kg}$ 、第 II 期は、青草 (オーチャードグラス) を体重 $100 \mathrm{Kg}$ 当り $8 \mathrm{Kg}$ 、第吕期には乾草（オーチャードグラス）を体重 $100 \mathrm{Kg}$ 当り 2 , Kg給与して 1 日の量とし、 各期とも 1 日 3 回に分けて給与した。水は自由飲水とし、その他少量の食塩を与えた。

2. 試験 2 ： 肥育開始後同一環境下で同一飼料を給与し、 1 か月間飼養した 8 才および 12 才の黒 毛和種雌牛 2 頭を用いた。試験期間は試験 1 と同じ方法とし、給与飼料は、それぞれ第 I 期にはトウモ ロコシ萃葉サイレージを体重 $100 \mathrm{Kg}$ 当り $8 \mathrm{Kg}$ 、第 II 期にはトウモロコシ菜葉サイレージを体重 $100 \mathrm{Kg}$ り $8 \mathrm{Kg}$ に大麦挽砕を体重 $100 \mathrm{Kg}$ 当り $2 \mathrm{Kg}$ 、第 III 期には再び第 I 期と同じ飼料を同量給与した。

反忽胃内容液は、各試験期終了日の翌朝給慨前に胃カテーテルを用いて採取した。採取した試料は、 WARNER $^{13}$ の手順に従って直ちにMH S液（１０％ホルマリン溶夜１とに 8.5 gの食塩を溶かし、0.3

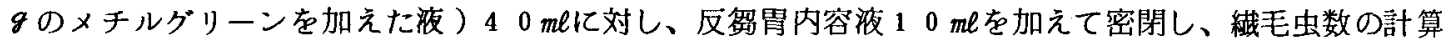

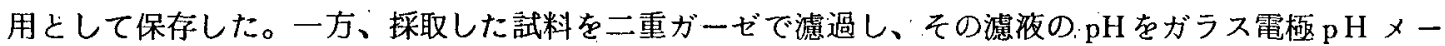
ターを使用して測定した。繊毛虫数の計数は、FUCHS-ROSENTHAL 計算板を使用して行ない、同一試料 について 3 回計数してそれぞれの平均值を求めだ。

V F A 総量は、CONWAY の微量拡散法 ${ }^{14)}$ により測定し、V F A 分画はガスクロマトグラフィーを用い

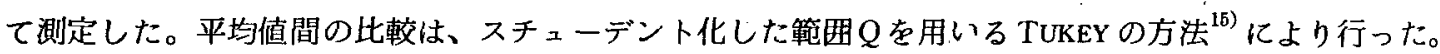
また、織毛虫類の分類は栗原 ${ }^{16)}$ の記述に従った。

結果

\section{1: 試験 1}

試験 1 の結果は表 1 に示した。繊毛虫類の総数は、各期間の比較において、試験期の進むに従って有 意な减少を示し、第II期には第 I 期の $1 / 7$ 、第吕期では約 $1 / 20$ に減少した。このうち全毛虫類の I sotricha 属およびDasytricha 属とも第 I 期と第II 期では変化を示さなかったが、第吕期に移行しては ビめて有意に城少し、ほとんど認められなくなっだ。一方、負毛虫類においては、Entodinium属と Diplodinium属に対称的な変化が現われた。すなおち、Entodinium 属は第 I 期で $297.4 \times 10^{-3} \mathrm{ml}$ 数 え、総数の $48.3 \%$ を占めていたが、第II 期 (青草)、第且期（乾草）と移行するに従って有意に減少 し、1／11 および 1/49 亿减少した。Diplodinium属では、第I期（大麦十稲わら）ではほとんど実現

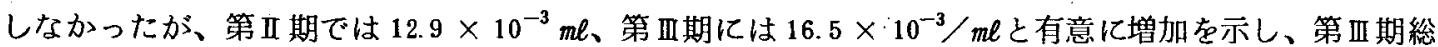
数の $55.2 \%$ 占めるまでになった。しかし同じ貧毛虫類でもEpidinium 属は、試験期の進むにつれ第 III期に有意に減少を示したものの、第II 期では同期総数に対する割合ではかえって増加を示した。

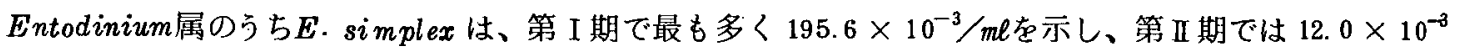
$/ m \ell$ と $1 / 16$ に減少した。さらに第亚期では $2.5 \times 10^{-3} / m \ell$ と最低值になり、第 $\mathrm{I}$ 期の $1 / 78$ に激減し た。しかしながらEntodinium属の他の種類は一定の㑯向を示さなかった。

\section{2. 試験 2}

試験 2 の結果は表 2 に示した。繊毛虫類の総数は、第 $\mathrm{I}$ 期 (サイレージ)加ら第 II 期 (サイレージ十 大麦）に移行するに従って有意な増加を示し、第 II 期から第期（サイレージ）に移行して有意な诚少

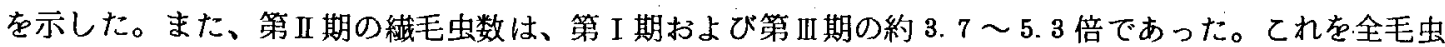
類と貣毛虫類に分けて検討してみると、全毛虫類のI sotricha 属は、各試験期の比較で有意差を示さな かったが、Dasytricha 属では第 III 期で第 I 期および第II 期に比較して有意な減少を示した。てれに反し 
Table 1. Changes in the number of rumen ciliate protozoa in each experimental period.

(Experiment 1)

\begin{tabular}{|c|c|c|c|}
\hline Ciliata & $\left(\begin{array}{c}\text { I } \\
\text { ground barley }+ \\
\text { rice straw }\end{array}\right)$ & $\begin{array}{c}\text { Experimental period } \\
\text { II } \\
\text { (grass) }\end{array}$ & $\begin{array}{c}\text { III } \\
\text { (hay) }\end{array}$ \\
\hline Holotrichs & \multicolumn{3}{|c|}{ 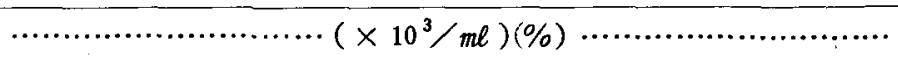 } \\
\hline Isotricha & $3.0 \pm 1.5^{2}(0.5)$ & $2.8 \pm 1.9^{\mathrm{a}}(3.0)$ & $0.1 \pm 0.1^{\mathrm{D}}(0.2)$ \\
\hline Dasytricha & $6.0 \pm 2.8^{a}(1.0)$ & $6.2 \pm 2.4^{a}(7.0)$ & $0.2 \pm 0.2^{\mathrm{b}}(0.6)$ \\
\hline \multicolumn{4}{|l|}{ Entodiniomorphs } \\
\hline Entodinium & $297.4 \pm 14.8^{\circ}(48.3)$ & $27.6 \pm 3.1^{\mathrm{b}}(31.5)$ & $6.0 \pm 1.5^{\mathrm{b}}(20.0)$ \\
\hline E. simplex & $195.6 \pm 12.1(31.8)$ & $12.0 \pm 2.0(13.7)$ & $2.5 \pm 0.6(8.3)$ \\
\hline$\left\{\begin{array}{l}\text { Other species } \\
\text { of Entodinirm }\end{array}\right.$ & $101.8 \pm 3.0(16.5)$ & $15.6 \pm 0.9(17.8)$ & $3.5 \pm 0.5(11.7)$ \\
\hline Diplodinium & $0.1^{a}(0.001)$ & $12.9 \pm 2.1^{\mathrm{b}}(14.7)$ & $16.5 \pm 2.6^{\mathrm{b}}(55.2)$ \\
\hline Epidinium & $11.1 \pm 1.0^{\mathrm{a}}(0.2)$ & $10.7 \pm 1.1^{a}(12.2)$ & $1.2 \pm 0.5^{\mathrm{b}}(4.0)$ \\
\hline Total number & $615.4^{\circ}(100)$ & 87. $7^{\circ}(100)$ & $29.9^{\circ}(100)$ \\
\hline
\end{tabular}

$a, b, c$. Means not having the same superscript letter are significantly different $(P<0.05)$

Table 2. Changes in the number of rumen ciliate protozoa and some properties of rumen fluid in each experimental period. (Experiment 2)

\begin{tabular}{|c|c|c|c|}
\hline Ciliata & $\begin{array}{c}\mathrm{I} \\
\text { (silage) }\end{array}$ & $\begin{array}{c}\text { Experimental period } \\
\text { II } \\
\left(\begin{array}{c}\text { ground barley }+ \\
\text { silage }\end{array}\right)\end{array}$ & $\begin{array}{c}\text { III } \\
\text { (si lage) }\end{array}$ \\
\hline Holotrichs & \multicolumn{3}{|c|}{ 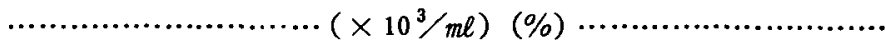 } \\
\hline I sot richa & $9.1 \pm 1.1(6.0)$ & $10.6 \pm 1.7(2.0)$ & $9.5 \pm 2.8(8.0)$ \\
\hline Dasytricha & $26.5 \pm 5.2^{a}(17.6)$ & $29.7 \pm 2.1^{a}(5.0)$ & $8.5 \pm 1.1^{\mathrm{b}}(8.0)$ \\
\hline \multicolumn{4}{|l|}{ Entodiniomorphs } \\
\hline Entodinium & $51.3 \pm 0.7^{a}(34.0)$ & $284.8 \pm 0.9^{\mathrm{b}}(43.0)$ & $41.9 \pm 1.8^{\mathrm{a}}(37.0)$ \\
\hline E. simplex & $18.3 \pm 0.7(12.0)$ & $145.7 \pm 3.1(22.0)$ & $13.0 \pm 0.9(12.0)$ \\
\hline E. nanellum & $20.5 \pm 2.5(14.0)$ & $118.4 \pm 18.0(18.0)$ & $16.5 \pm 1.4(15.0)$ \\
\hline $\begin{array}{l}\text { Other species } \\
\text { of Entodinium }\end{array}$ & $12.5 \pm 1.3(8.0)$ & $20.7 \pm 1.3(3.0)$ & $12.4 \pm 0.8(11.0)$ \\
\hline Diplodinium & $11.5 \pm 0.9^{a}(8.0)$ & $32.3 \pm 0.7^{6}(5.0)$ & $9.0 \pm 0.4^{2}(8.0)$ \\
\hline Epidinium & $1.6 \pm 0.2^{a}(1.0)$ & $13.7 \pm 0.4^{\mathrm{b}}(2.0)$ & $1.5 \pm 0.2^{\mathrm{a}}(1.0)$ \\
\hline Total number & $100.0^{\mathrm{a}}(100)$ & $371.0^{b}(100)$ & $70.4^{a}(100)$ \\
\hline $\mathrm{pH}$ & 7.24 & 7. $33 \pm 0.01$ & $7.46 \pm 0.02$ \\
\hline Total VFA $(\mathrm{m} \mathrm{mol} / 100 \mathrm{~m} \ell)$ & $5.25 \pm 0.68$ & $6.02 \pm 0.83$ & $5.72 \pm 0.18$ \\
\hline VFA fraction & n. & $\cdots \cdots \cdots(\operatorname{mol} \%) \cdots \cdots \cdots$ & , \\
\hline Acetic acid & $51.8 \pm 3.4$ & $51.2 \pm 0.5$ & $54.1 \pm 0.4$ \\
\hline Propionic acid & $23.9 \pm 1.9$ & $25.0 \pm 0.2$ & $25.1 \pm 0.2$ \\
\hline Butiric acid & $20.9+1.1$ & $20.8 \pm 0.1$ & $19.1 \pm 0.6$ \\
\hline Valeric acid & $3.4 \pm 0.2$ & $3.1 \pm 0.6$ & $1.6 \pm 0.1$ \\
\hline
\end{tabular}

a, b) Means not having the same superscript letter are significantly different $(P<0.05)$ 
て負毛虫類の各属は、第II期で第 I 期および第 III 期に比較して同じ傾向を示した。この变化は総数の増 娍と同様の変化であった。とのうち Ent odinium属は最も著明な変化を現わし、第II期で明らかに5.6〜 6.8 倍の有意の増加を示し、第II期で総数の 43.0\%を占めた。著しい変化を示したEntodinium属のう ちE. simplexとE. nanel lum 2 種類は類似の㑯向を示した。すなわち第 II 期では第 I, III 期に比べ E. simplex で 8.0〜 11.2 倍の増加を示し、E. nanellumでは 6.5〜 7.2 倍の数が認められた。しかしな がらEntodinium属の他の種類は一定の傾向がなかった。また、Dipl odinium属とE pidinium 属も総数 の変化と類似の型を示したが、出現数が少なく、各試験期総数の1.0〜8.0\%を占めるに過ぎなかった。

各試験期の反忽胃内容液の $\mathrm{pH}$ は $7.24 \sim 7.46$ の範囲を示し、試験期の進むに従って若干アルカリに 傾いた。V V A 総量は試験期を通して $5.3 \sim 6.0 \mathrm{mmol} / 100 \mathrm{m \ell}$ であっだ。VFAのうち、酢酸、プロピオン 酸、酪酸および吉草酸はそれぞれ 51.8〜 54.1、23.9〜25.1、19.1〜20.9 および $1.6 〜 3.4 \mathrm{~mol} \%$ であ った。

考察

武智ら ${ }^{4)}$ の報告によると、雄メン羊で乾草十濃厚飼料からビートパルプ単味給与に切換え、さらに前 の乾草十濃厚飼料に戻したところ、ビートパルプ単味給与期に繊毛虫類が消失し、乾草十濃厚試料に転 換給与後 160 日間も継続観察したが、繊毛虫類は出現しなかった。NAKAMURA and KANEGASAKI ${ }^{8)}$ の報 告でも特に乾草単味給与では、その数の減少が著しかったと述べている。著者らの今回の試験結果も、 それらの知見と一致した。

飼料の差による影響は、全毛虫類よりも貧毛虫類に明らかに現われ、特に粗飼料に濃厚飼料を加えて 給与したときに著しく增加した。このうちでもEntodinium属は顕著であった。このととは大方の研究 者 $^{7,8,11,12,17)}$ も報告していることから、Entodinium属が反贸胃内織毛虫数堌減の主役であると考えられ る。NAKAMURA and KANEGASAKI ${ }^{8)}$ は、メン羊を用いて試験を行ない、E. simplex, E. longinucleatum およびE. caudatumの 3 種類がEntodinium 属のうちで最も増娍が著明であったが、E. nanellumの濃厚 飼料に対する依存度は、前の 3 種類と明らかに異なっていると報告した。そしてての理由として $E$. nanel lumは最も小型の絨毛虫であるため、他の中・大型のEntodinium 属の各種のように、澱粉粒を取 込むととが出来なくて、むしろ乾草中に含まれる可溶性の炭水化物を利用するかも知れないと述べた。

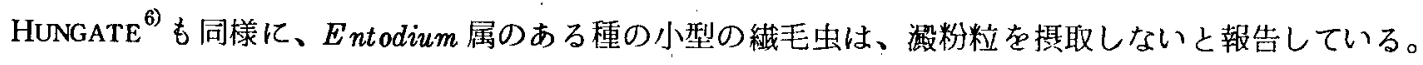
一方、VAN DER WATH and MYBURGH ${ }^{18)}$ は、小麦わらを基本飼料とし、とれにトウモロコシを加えてメン 羊に給与し瀻毛蝢を観察した。そして、E. simplex は、トウモロコシの制限給与に対して, $E$. nanellumよりも抵抗力があると報告した。著者らの今回の試験では、E. simplex と E. nanellumが蔚粉 質飼料 (大麦) に敏感に反応し增加した。むしろ、E. longimucl eatum と E. condatumはE. minimump $E$. vorax と同椂に一定の㑯向は示さなかった。これらの差異は、実験方法や試験を実施する際の環境等 の相違によるものと思われる。しかしながら、今回の試験に関する限り、Entodinium属のうち、E. timplex は、繊毛虫数の増减に支配的役割を果たしていると考えられた。

文献

1) Purser, D. B. and R. J. MOIR, Aust. J. Agric. Res., 1:555-564. 1959.

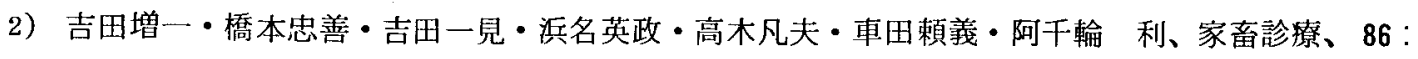


10-22. 1970 .

$3 ）$ 神立 誠・堀口雅昭・ 久保辰雄・高橋直躬、農林水産技術会議研究成果、21：153-175. 1965.

4）武智辰夫・栗原 康・柴田章夫、日畜会報、学会号、43:31. 1972.

5) 広瀬可恒、乳牛の栄養と飼養、62-80. 朝倉書店. 東京. 1949 .

6) Hungate, R. E, The rumen and its microbes. 92. Academic Press Inc. New York and London. 1966.

7) WARNFr, A. C. I, Physiology of digestion in the ruminant. 364. Butterworths Inc. London. 1965.

$8)$ NAKAMURA, K. and S. KanegaSAKI, J. Dairy.Sci., 52:250-255. 1969.

9）佐々木正雄・山谷洋三・大谷 勲、日畜会報、学会号、43：35. 1972.

10) Oltjen, R. R. Williams, J. A nim. Sci., $38: 915-920.1974$.

11) AвE, M., H. ShibUi., T. IRIKI and F. KUMENo, Br. J. Nutr., 29: 197-201. 1973.

12）日野常男・亀高证夫、日畜会報、45：223-231. 1974 .

13) Warner, A. C. I, J. Gen. Microbiol., 28 : 119-128. 1962.

14）石坂音吉、微量拡散分析法. 69-71. 有江堂. 東京. 1969.

15）吉田 实、畜産を中心とする実験計画法. 84-86. 養賢堂. 東京. 1975.

16）栗原 康、日獣会誌、22：132-151. 1969.

17）星野貞夫、日畜会報、45：214-215. 1974 .

18) Van Der Wath, J. G. and S. T. MYburGh, J. Vet. Sci. Anim. Ind., 17:61. 1941. 